\title{
わが国に打けるイチゴ育種研究の成果と展望
}

望月龍也

（農林水産省野菜·茶業試験場, 三重県安芸郡安濃町草生 360, 干 514-2392)

\section{Progress and future aspects of strawberry breeding in Japan}

Tatsuya Mochizuki

(Department of Vegetable Breeding, National Research Institute of Vegetables, Ornamental Plants and Tea, Kusawa, Ano, Age, Mie 514-2392, Japan)

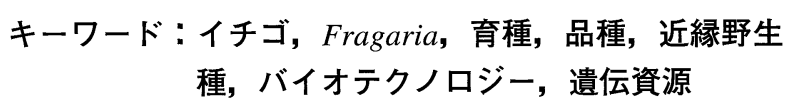

\section{1.はじめに}

現在の栽培イチゴ $($ Fragaria $\times$ ananassa $)$ は，18 世紀中 頃にオランダで作出されたチリイチゴ(F. chiloensis) と バージニアイチゴ(F.virginiana)の種間雑種に由来する 比較的新しい作物である. 現在では温帯〜亜寒帯地域は もとより，生態的には必ずしも適地といえない熱带高原 地域にも栽培が広がり, 世界的な園芸作物となっている。 FAO 統計によれば，1998年の世界上位20カ国における 生産量は約 235 万 $\mathrm{t}$, 国別ではアメリカ (約 74 万 $\mathrm{t})$, スペ イン (約 31 万 $\mathrm{t})$, 日本 $($ 約 20 万 $\mathrm{t})$, 韓国, ポーランド $($ 約 15 万t) 等が多い(柳 2000).

わが国の 1998 年における作付面積は 7,640 ha，出荷量 は $181,000 \mathrm{t}$ ，また全卸売市場における取扱金額は園芸品 目中ではミカンに次ぎ, リンゴやトマト, キュウリ等よ り多い約 2,200 億円に達している. 全国のイチゴ生産量 は 1980 年代中頃から 20 万 $\mathrm{t}$ 前後を維持してきたが，作 付面積は漸減傾向にあり，1998年の作付面積は 1985 年 の約 $70 \%$ でる。単収向上の要因としては, 栽培管理 技術の改善もあるが, 最大の要因は促成長期どり作型の 拡大にある。

全出荷量の $90 \%$ 以上を占める温暖地・暖地のビニル 八ウス促成栽培では, 1980 年代中頃から“女峰, とょの か’の 2 大品種時代が続いてきた。これらの品種は, 早 生で休眠が浅いため促成長期どり作型への適応性が高 く, さらに, 夏季低温処理育苗による人為的な花芽分化 促進技術が確立されたことから，収穫期間は $11 \sim 5$ 月 と半年あまりに及んでいる。促成栽培では, 頂果房に引 き続き第 3 ないし第 4 次腋果房まで連続的に収穫するた め, 気象条件による収量の年次間差が小さく, 平均的な 収量は3.5 4.0 t/ $10 \mathrm{a}$ であり, 市場価格もここ 10 年来

2000 年 6 月 16 日受領
年平均 $1,100 \sim 1,300$ 円 $/ \mathrm{kg}$ と変動が小さい安定収益作物 であることから, 産地では地域を支える基幹作物に位置 づけられている。

ここでは, 野菜・茶業試験場における研究を中心に, わが国における最近のイチゴ育種の現状と成果を概説す るとともに，今後の課題について検討する.

なお，わが国における栽培イチゴの導入から最近まで の品種及び栽培技術等の変遷については, 本多(1983)及 び望月 (1997)を参照されたい.また海外におけるイチゴ 育種の状況は, 国際園芸学会が 4 年ごとに開催する国際 イチゴシンポジウムに紹介されている (Acta Horticultural No. 265(1988), No. 348(1992), No.439(1996)).

\section{2. 育種目標}

促成イチゴ生産に要する労働時間は, 育苗から収穫・ 出荷まで含めると年間 $2,000 \sim 2,500$ 時間 $/ 10 \mathrm{a}$ と推定さ れ, 労働生産性の面から大幅な省力化が必要である. 特 に労働時間の $50 \sim 60 \%$ を占める収穫・選果作業は省力 化が最も必要な部分であり, また高温期の集約的な管理 を必要とする育苗作業は労働時間の $10 \%$ 強ではあるが, 生産者にとって最も負担感が強い作業であることから, これらの省力化に対応できる品種育成が求められてい る.

果物であるイチゴでは品質は基本的かつ重要な特性で あるが，促成栽培の拡大と並行して，広域流通による全 国的な安定供給が達成されるとともに, 最近では高品質 と合理的価格のバランスを重視する消費傾向が強まって おり，流通適性に優れる品種が求められている。またわ が国のイチゴ生産は歴史的に少数品種寡占の傾向が強か ったが，他の果実類と互して消費ニーズを拡大していく ためには, 品質面で個性ある品種の開発が求められてい る.

食品の健全性に対する消費ニーズが拡大し，また農業 生産に扔ける環境負荷低減が重要課題になっているが, 生果でしかも剥皮せずに消費されるイチゴでは，特に消 費者の関心が高い。このようなニーズに対応するために 


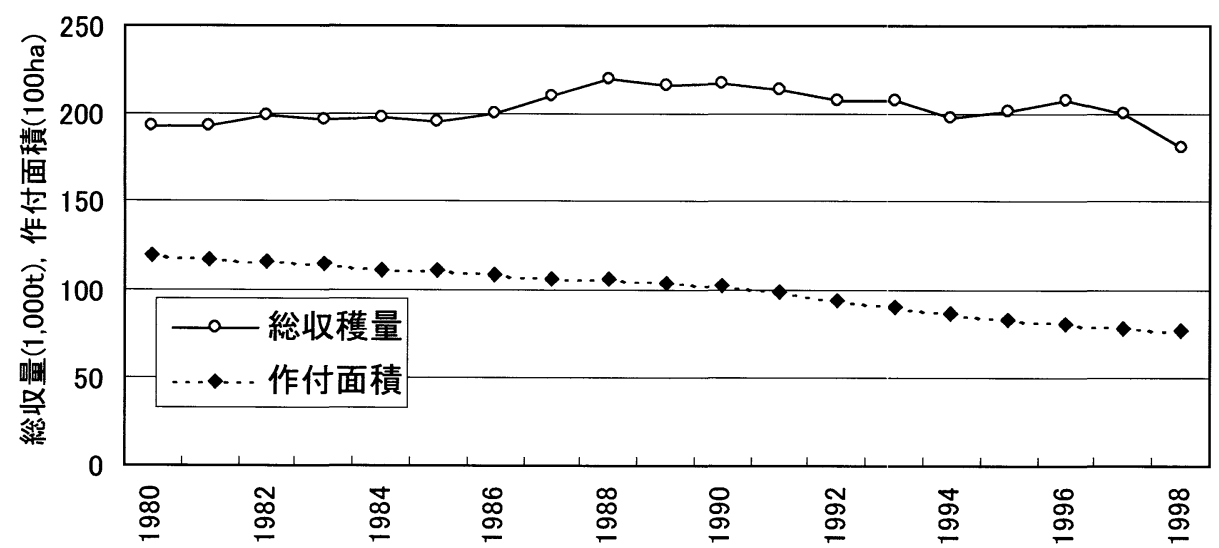

図 1.イチゴ生産の年次間推移

は病害虫抵抗性品種が必須である。わが国のイチゴ生産 では炭そ病・うどんこ病・萎黄病・疢色力ビ病・八ダ ニ・アブラムシ等が重要であり,さらに最近は萎凋病・ 葉枯机炭そ病・ミカンキイロアザミウマ等の発生も拡大 しているが，病害虫抵抗性を主目標に育成された品種は ごく少なく, 特に重要病害に対する複合抵抗性品種は皆 無に近いことから，早急な開発が求められている.

夏秋期は業務用 (ショートケーキ等)中心のため需要が 少なく, 生産量は冬春期の $1 / 10$ 以下である. しかし業 務用需要は堅調で, 価格も安定しており, 安定生産可能 な優良品種とこれを利用した作型が開発されれば，寒高 冷地を中心に相当の生産拡大が見込まれる。また温暖地 や暖地でも, 中山間地活性化対策として, 四季成り性品 種を利用した夏秋期生産に期待が大きい。さらに昭和 50 年代初頭から, 生産量の少ない夏秋期の業務用とし てカリフォルニアから生果が輸入され，最近では年間 $5,000 \mathrm{t}$ 近くに達しており, 輸入依存割合を低下させるた めにも，夏秋期栽培に適した品種の開発が求められてい る.

このような品種開発へのニーズを背景に, 近年は新品
種の発表が相次いでおり, その中から促成栽培では‘と ちおとめ’(石原ら 1996), ‘章姫” (萩原 1995), “さちの か’ (森下ら 1997) 等，また露地～夏秋栽培では ‘北の輝” （沖村ら 1997）等が普及しつつある.しかし，これらの 新品種も省力性・病害抵抗性・流通適性等の点で十分で はなく, 一層の育種努力が求められている.

\section{3. 省力・軽作業化}

\section{1）収穫・選果作業}

果実が軟弱で傷みやすく，また商品性の点からサイ ズ・形状. 着色等の規格に合わせた選別が不可欠なイチ ゴでは, 人手による収穫と選果を基本とせざるを得ない ため, 収穫 - 選果の省力化には収穫しやすい果房特性 (直立性, 果実配置の揃い等) と選果を容易にする果実の 着色・形状の揃い, 果実の大きさ及び果実硬度等が重要 である。

収穫しやすい着果習性及び果実サイズの斉一化を可能 とする果房型特性の解明に基づき(竹内 1993, 曾根ら 1998), 収穫 - 選果作業の省力化が可能な“久留米 56 号,

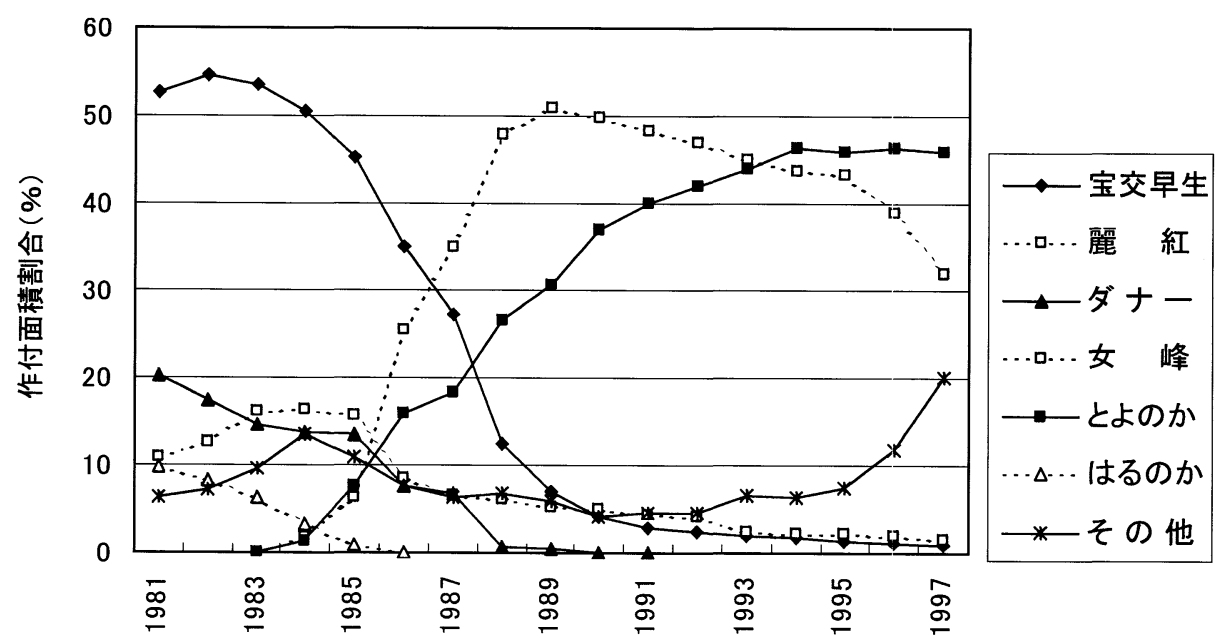

図2. 促成栽培におけるイチゴ作付品種の変遷 
同 57 号’が育成された(望月ら 2000)。これらは，果房形 態の改造を育種目標として育成された最初の系統であ り，“久留米 56 号” は基部から発生する 1 本の強い果梗 から篣状に着果する分枝型, ‘同 57 号” は基部から発生 する多数の強い果梗に各 $1 \sim 2$ 果着果する直枝型の果房 を有し，いずれも果実サイズの斉一性に優れている．将 来的には果実硬度を強化することにより，機械選果によ る一層の省力化を可能とする品種の育成が期待される.

一方イチゴのように手収穫が基本となる作物では，果 実は大きいほど収穫効率が高く, 世界最大のイチゴ産地 カリフォルニアにおいても数年前から極大果品種 'Camarosa'が主力を占めている，わが国の促成栽培にお ける極大果品種としては‘アイベリー’が有名であるが, 極大果数を増加させるためには厳冬期の草勢管理に熟達 した技術を必要とすること等から，作付面積は減少傾向 にある。 ‘久留米 54 号’は，“とよのか’及び‘アイベリー’ を材料に, 自殖と大果性に関する選抜を 3 世代繰り返し て作出した系統間の交配により育成された中間母本系統 であるが(望月ら 1996)，厳冬期にも草勢低下せず連続 的な極大果生産が可能であり，極大果性の交配親として 能力が高いため, 交配母本としての活用が期待される.

\section{2）育苗及び本圃管理}

育苗面では，病害回避や作業姿勢改善に効果の高い高 設採苗方式, 省力効果に優れ機械化移植への適応性も高 いセルトレイ等小型容器育苗, さらには極めて省力的で あり育苗一生産分業にも有効な無仮植育苗等に対する 適性が求められる。このためには発根性, 活着性, 草姿 (立性, 小型葉等), さらには頂花房や腋花房分化の環境 安定性等が重要である。これらの形質には明らかな品種 間差が見られるが，品質優先のわが国ではこれまではあ まり配慮されておらず, 今後の検討が必要な分野である.

種子繁殖型品種は, レタスやキャベッ等の葉菜類やト マトやキュウリ等の果菜類で広く利用されている育苗セ
ンター方式等により, 育苗 - 生産分業による省力化に 有効と考えられる。一般的にイチゴは遺伝的なへテロ性 が高く，また固定系統育成には自殖弱勢の問題がある. しかし最近オランダで四季成り性を利用した種子繁殖型 品種が開発されており (Bentvelsen and Bouw 2000), わが 国でも実用品種からの自殖系統利用 (成川ら 1997, 斉藤 ら 1998），あるいは八倍性栽培種への二倍性野生種のゲ ノム添加による合成十倍体の利用(望月ら 1994)による 形質固定等が試みられている.

本圃管理では，大幅な省力・軽作業化効果が期待され る NFT 耕, ロックウール耕, 養液土耕等による高設栽 培に注目が集まっているが, 現状ではこのような栽培方 式に対する適応性には品種間差異がみられる，無培地あ るいは少量培地栽培に特有な培地温度や養液濃度の変動 に対する適応性，また導入コストを早期回収するための 多収性や密植適性等が必要であり, 生理生態面等からの 研究深化が望まれる(田中1998).

\section{4. 病害抵抗性}

\section{1）炭そ病抵抗性}

野菜・茶業試験場では，育種における抵抗性の簡易検 定法として葉柄浸漬接種法 (Noguchi et al. 1994)が開発さ れ，またフロリダ州立農試等から導入した抵抗性品種・ 系統を素材に高度抵抗性交配母本系統“久留米素材 1 号, 同 2 号’が育成された (Noguchi et al. 1998)，これらの系 統は, わが国で発生する炭そ病菌に対して素材品種・系 統以上に安定した抵抗性を有しており，炭そ病抵抗性の 交配母本としての活用が期待される. また, 抵抗性育種 の基盤となる遺伝情報等に関する研究は国内外とも少な いが, 最近実生への人工接種を利用した循環選抜の効果 が明らかにされ(森1998), これに基づいて実用的な抵 抗性品種が育成された(森 2000a).
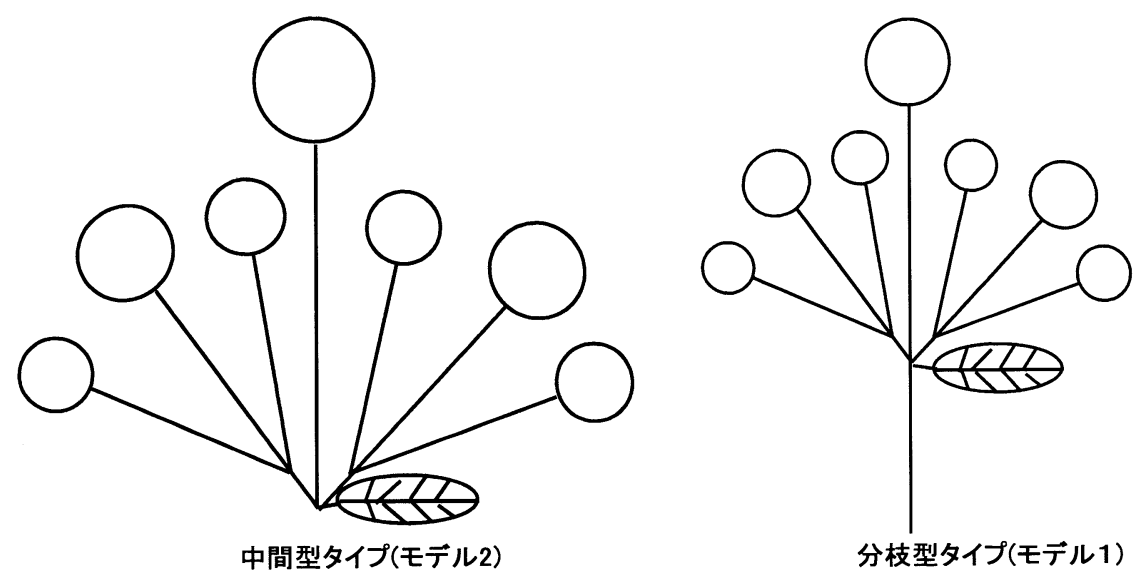

図3、果実サイズの斉一性を高めるための果房型モデル (久留米 56 号：モデル 1 , 久留米 57 号：モデル 2) 
表1. 主要病害抵抗性に関する品種間差(野菜茶試久留米支場, 1998)

\begin{tabular}{lccclccc}
\hline \hline 品種名 & うどんこ病 & 萎黄病 & 炭そ病 & 品種名 & うどんこ病 & 萎黄病 & 炭そ病 \\
\hline アイベリー & $\mathrm{S}$ & $\mathrm{S}$ & $\mathrm{S}$ & 女峰 & $\mathrm{IS}$ & $\mathrm{IS}$ & $\mathrm{S}$ \\
あかねっ娘 & $\mathrm{RI}$ & $\mathrm{S}$ & $\mathrm{IS}$ & 章姫 & $\mathrm{IS}$ & $\mathrm{RI}$ & $\mathrm{S}$ \\
アスカウエイブ & $\mathrm{IS}$ & $\mathrm{R}$ & $\mathrm{IS}$ & 大石四季成 & $\mathrm{RI}$ & $\mathrm{R}$ & $\mathrm{I}$ \\
てるのか & $\mathrm{R}$ & $\mathrm{S}$ & $\mathrm{R}$ & 栃の峰 & $\mathrm{RI}$ & $\mathrm{IS}$ & $\mathrm{S}$ \\
とよのか & $\mathrm{S}$ & $\mathrm{IS}$ & $\mathrm{I}$ & 八千代 & $\mathrm{R}$ & $\mathrm{RI}$ & $\mathrm{R}$ \\
はつくに & $\mathrm{I}$ & $\mathrm{R}$ & $\mathrm{R}$ & 福羽 & $\mathrm{S}$ & $\mathrm{R}$ & $\mathrm{I}$ \\
はるのか & $\mathrm{S}$ & $\mathrm{I}$ & $\mathrm{RI}$ & 宝交早生 & $\mathrm{R}$ & $\mathrm{S}$ & $\mathrm{R}$ \\
はるよい & $\mathrm{RI}$ & $\mathrm{S}$ & $\mathrm{I}$ & 芳玉 & $\mathrm{S}$ & $\mathrm{R}$ & $\mathrm{S}$ \\
ひのみね & $\mathrm{R}$ & $\mathrm{RI}$ & $\mathrm{IS}$ & 堀田ワンダー & $\mathrm{S}$ & $\mathrm{RI}$ & $\mathrm{I}$ \\
ひみこ & $\mathrm{I}$ & $\mathrm{I}$ & $\mathrm{R}$ & 明宝 & $\mathrm{R}$ & $\mathrm{S}$ & $\mathrm{R}$ \\
ベリースター & $\mathrm{R}$ & $\mathrm{RI}$ & $\mathrm{S}$ & 麗紅 & $\mathrm{S}$ & $\mathrm{S}$ & $\mathrm{S}$ \\
ベルルージュ & $\mathrm{IS}$ & $\mathrm{RI}$ & $\mathrm{RI}$ & とちおとめ & $\mathrm{IS}$ & $\mathrm{IS}$ & $\mathrm{IS}$ \\
さちのか & $\mathrm{IS}$ & $\mathrm{IS}$ & $\mathrm{S}$ & 濃姫 & $\mathrm{IS}$ & $\mathrm{IS}$ & $\mathrm{S}$ \\
\hline
\end{tabular}

$\mathrm{R}$ ：抵抗性, RI：やや抵抗性, I：中間, IS：やや罪病性, S : 罹病性

表2. 炭そ病抵抗性素材“久留米素材 1 号, 同 2 号”の特性(野菜茶試久留米支場, 1998)

\begin{tabular}{|c|c|c|c|c|c|c|c|}
\hline \multirow[b]{2}{*}{ 品種·系統 } & \multicolumn{2}{|c|}{ 炭そ病接種 } & \multicolumn{5}{|c|}{ 促成栽培 } \\
\hline & 葉柄発病度 & 枯死株率 $(\%)$ & 成熟日 & 総収量 $(\mathrm{kg} / \mathrm{a})$ & ) 商品果 1 果重 & 糖度 $(\%)$ & 酸度 $(\%)$ \\
\hline 久留米素材 1 号 & 0.17 & 8.5 & $1 / 16$ & 241.0 & 10.2 & 7.1 & 0.55 \\
\hline 久留米素材 2 号 & 0.43 & 0.0 & $1 / 9$ & 194.9 & 11.8 & 7.6 & 0.49 \\
\hline とよのか(罹病性) & 2.07 & 20.6 & $1 / 2$ & 227.6 & 20.7 & 10.3 & 0.49 \\
\hline Dover(抵抗性) & 0.90 & 18.3 & - & - & - & - & - \\
\hline
\end{tabular}

炭そ病接種 $: 3$ 年間の平均值 (葉柄発病度 : 無病斑 0 葉柄折損 4$)$, 総収量 $: 3$ 月末まで

\section{2）うどんこ病抵抗性}

うどんこ病は収穫期間中の発生が多いため，生産上の 実害が大きいばかりでなく，殺菌剤散布は生産物の食品 としての健全性にも関わることから，抵抗性品種育成が 最も急がれる病害である。うどんこ病菌は活物寄生性で 人工培地での培養や保存が困難であるため, レース分化 等病原菌の遺伝的多様性に関する研究や抵抗性発現機作 に関する研究は遅れていたが, 最近単胞子分離株の利用 によって，わが国には少なくとも2種のレースが存在す ることが明らかにされた(内田・井上 1998)。 また育種 のための効率的かつ再現性の高い抵抗性検定方法とし て，切断葉あるいリーフディスクを利用した検定法が開 発されている。ささらに抵抗性の遺伝に関しては，ダイア
レルクロス解析により有効因子数や組合せ能力が推定さ れている(斉藤・後藤 1997).

\section{5. 果実品質}

\section{1）果実成分}

イチゴ果実に含まれる成分の中でも，食味に直接的に 関わる糖・有機酸及びビタミン C は最も重要な成分と考 えられる．最近これらの含量及び組成の多様性，あるい は環境安定性に着目した品種特性の解明が進んでいる （萩原ら 1998，兽根ら 1997，曽根ら 1999）。特にビタミ ンC含量については，遺伝解析を踏まえ(曾根ら 2000)， 安定高ビタミンC含量系統 $(120 \mathrm{mg} / 100 \mathrm{~g}$ 以上が目標)の

表3. イチゴ品種における糖・有機酸組成及びビタミンC含量の多様性(野菜茶試久留米支場，1996)

\begin{tabular}{lccccc}
\hline \hline & 単位 & 平均值 & 標準偏差 & 最大値 & 最小値 \\
\hline 全糖含量 & $\%$ & 48.6 & 14.3 & 96.6 & 21.5 \\
Suc./Fru. & $\%$ & 82.1 & 7.02 & 98.0 & 58.1 \\
有機酸含量 & $\%$ & 5.19 & 1.21 & 12.90 & 1.60 \\
Mal./Cit. & $\%$ & 20.3 & 14.1 & 122.5 & 5.3 \\
ビタミンC & $\mathrm{mg} / 100 \mathrm{~g}$ & 59.0 & 18.0 & 132.4 & 15.9 \\
\hline
\end{tabular}

供試品種数：257, Suc.：スクロース, Fru.：フルクトース, Mal.：リンゴ酸, Cit.：クエン酸 
選抜が進められている.

Fragariaはラテン語の Fragrans（香りのよい）に由来し ており，優れた香気性はイチゴの特徵である．イチゴ近 縁野生種との種間交雑により多様な香気特性を有する素 材の開発が進められており，これまでに，香気特性に関 わる揮発性成分組成 (特にエステル類)が栽培イチゴと全 く異なり，モモあるいはスモモ類似の香気を有する‘久 留米 IH 1 号, (野口ら 1995)をはじめとする多様な 10 倍 体複倍数性種間雑種系統を育成した。これらの系統はこ れまでのイチゴの範疇を超えた多様な香気特性を有する ことから，新規用途開発や消費拡大が期待される。また 栽培イチゴへの戻し交雑における香気特性の遺伝性 (Mochizuki et al. 1997) や関連するDNA マーカーの検索 (李ら 1997)が試みられている.

イチゴ成熟果実の主たる色素である anthocyanを構成 する agricon(anthocyanidin)には cyanidin と pelargonidin が 知られているが, 結合糖類等については必ずしも一致し た見解が得られていなかった(枳穀ら 1995, Tamura et al. 1995). 最近多数品種による詳細な分析が行われ, 主た る anthocyan は pelargonidin-3-glucoside (Pg3G), cyanidin3-glucoside (Cy3G) 及び pelargonidin-3-malony glucoside $(\mathrm{Pg} 3 \mathrm{MG})$ であり, Pg3MGは全く含まれない品種から全 anthocyanの $30 \%$ 以上を占める品種まで幅広い変異のあ ることが示された(山口ら 1999). 果色は外観品質の主 要な要因であり, これらの研究が発展すれば, 果色を対 象とした育種の可能性が開けるものと期待される.

\section{2）流通適性}

外皮をもたないイチゴは本来的に流通適性の劣る果実 である。しかし果実硬度を高めることにより流通適性を 向上できることがアメリカにおける研究から明らかにさ れており, 我が国でも寒冷地の晚春〜夏秋期生産を対象 とした育種で成果を挙げてきた(門馬・上村 1978)。し かし低温期の促成栽培では流通適性の問題が相対的に大 きくなかったこともあり, 流通適性向上への育種的な対 応は遅れている。

イチゴ果実の硬さは果皮及び果肉の硬さに分別され， 両者は独立的に遺伝する形質と考えられており（門馬ら 1985)，遺伝率や選抜効果等も明らかにされている(森 2000b). 果皮硬度は日持ち性, また果肉硬度は輸送性と 関わりが深いことから, 流通適性付与を目指す場合には, 果皮と果肉の両者に配慮した選抜が必要であるが, 最近 の促成栽培用品種では‘さちのか’が両者ともに優れてお り, 流通適性が高い。また果実硬度を高めることは食味 低下に直結しやすいが(森下ら 1997)，“とよのか’の有 する成熟後の果肉軟化が遅い特性を利用することによ り, 必要以上に果実硬度を高めることなく, 優れた食味 と日持ち性の両立した品種を育成することが可能と考え られる(望月ら 1995).

また完全着色果への高濃度 $\mathrm{CO}_{2}$ 処理は果実硬度を不
可逆的に高め, 結果として流通適性向上に効果が高いた め(茶珍・後藤 1992), 長距離輸送を必要とするアメリ カでは実用技術になっている.この効果には品種間差が みられることから, 安定した流通技術開発のためには, 高濃度 $\mathrm{CO}_{2}$ 処理に対する反応に配慮した品種育成も検 討する必要があると考えられる。

\section{6. 夏秋期生産}

\section{1）四季成り性品種}

四季成り性品種とは，日長に関わりなく花芽を分化す る品種群である.これを夏秋期生産に利用するためには, 植物体形質では強い草勢, 優れたランナー増殖性, 安定 した四季成り性(高温下で短日条件に転じる 8 月以降に も花房数が減少しないこと)等, 果実形質では業務用主 体であるため, 果形の安定性, 十分な硬度, 優れた外観 等，また成熟期間が短い高温期の生産であるため，優れ た大果性 (果実肥大性) と食味 (特に糖度と酸度) 等が求め られる (沖村 2000).

これまで夏秋期生産用の育種親として多く利用されて きだ大石四季成” は, 四季成り性が安定しているものの, 高温期栽培に求められる果実肥大性や果実硬度等が十分 でなく, 本品種を素材として育成された品種もこれらの 点に問題があるものが多い.しかし交配親の選択により, 最近の育成品種には徐々に育種効果が現れており, 一層 の改良が期待される。またカリフォルニア大学で育成さ れた中日性 (day neutral) 品種 'Serva'も育種に利用されて きたが, 果実品質 (食味, 糖度)が劣るため, これまでの ところ普及性の高い実用品種は育成されていない，最近 はヨーロッパでも四季成り性品種の開発が活発化してお り(Simpson 2000), 今後はこれらの育種素材としての利 用を検討する必要がある。

一方, 寒冷地で育成された四季成り性品種は, 生態特 性面 (四季成り性の安定性, 休眠性とこれに起因するラ ンナー増殖性等)から西南暖地には適しておらず，また 温度等についてより不適な条件に対する適応性(肥大性, 果実硬度等) も求められることから, 温暖地や暖地に適 した四季成り性品種の育成が求められている。

\section{2）中間型品種}

中間型品種とは, 低温遭遇による休眠覚醒後の春〜初 夏の長日条件下において, 通常の品種と比べて早期に花 芽分化感受性を獲得する品種群であり, カリフォルニア のように冬季の低温が不十分な地域では四季成り性品種 と類似した開花生態を示す (柳 1992). カリフォルニア 大学で育成された“Pajaro’ は果実の大きさ, 硬さ, 形状 等に優れる中間型品種であり, 近年育種素材として広く 利用されている。野菜茶試(盛岡)では‘Pajaro’を交配親 とする中間型品種 ‘北の輝’を育成し, 夏秋穫り作型への 利用可能性を明らかにしており（沖村・五十嵐 1997）, 
寒冷地イチゴの新たな作型開発が期待されている.

\section{7. 育種方法}

\section{1）交雑育種}

現在の品種改良は世界的にみても交雑育種がほとんど であり，育成された品種は栄養繁殖により維持されてい る．イチゴは遺伝的なへテロ性が高く，ゲノム内に重複 が多いと考えられ，ほとんどの実用形質は量的遺伝を示 す。このため，内外の主要な育種組織では，毎年 5,000 〜 10,000 個体余の交雑実生個体から，優れた表現型を 示す実生を選抜し, 次年度以降に増殖 - 系統化し, 数年 間の選抜試験を経て品種を育成する方式がとられてお り，遺伝的知見に基づく育種は例外的といえる。

栽培イチゴでは，個別重要形質に関する遺伝情報が少 なく，また優良遺伝子型個体を得るためには大きな交雑 集団を必要とすることから，効率的な育種のためには「2 段階育種法」が有効である。この方法では， 1 年目は必 要とする個別形質を保有する品種間のできるだけ多くの 組合せについて，各40個体程度を栽培し，各組合せに おける特定組合せ能力の発現傾向を把握する。2 年目は 1 年目の結果から選定された少数の組合せについて，で きるだけ大きい集団 (1,000個体程度)から優良個体を選 抜する。この方式による交配親選抜の効果は対象形質に より異なるとされるが(Meulenbroek et al. 1996), 理論的 な検討は十分になされていない.

また自殖により目的形質に関する量的遺伝子を蓄積 し，あるいは不良な遺伝子を排除して交配親を作出し， これらの間の実生を選抜に供することにより，比較的小 さな育種規模で実用品種を開発する方式も提案されてお り, ‘麗紅’ (成川ら 1981), “久留米54号’ (望月ら 1996) 等が，本法により育成された。

\section{2）突然変異利用}

イチゴでは, 自然突然変異 (鬼怒甘等), あるいはカル ス培養 (新女峰, アンテール)や茎頂培養(アキタベリー) を利用した人為突然変異による品種が報告されている が，交雑育種による品種と比較してごく少ない。これは 実用形質の多くが量的遺伝子あるいは重複遺伝子に支配 されているため, 単因子に支配される劣性突然変異が表 現型に反映されにくいためと考えられる．また人為突然
変異源として, 化学変異源 $(\mathrm{MNU})$ や紫外線等が検討さ れてきたが, 実用品種が育成された事例はほとんどない. これは可視的な突然変異率を高めるほどの強い変異源処 理では, 染色体の欠損等により不稔等の劣悪変異を生じ やすいためと考えられる．イチゴ育種に有用な突然変異 誘起法は，今後の検討が必要な分野である.

\section{3）種間交雑}

現在の栽培イチゴは，育種に利用される遺伝子プール が比較的小さく, 異質(部分同質)八倍体の複雑なゲノム 構成が比較的多様な品種分化を可能としてきたと考えら れるものの, 病害抵抗性等の重要特性に対して, 栽培種 内に十分な遺伝変異が認められない場合も多い. 一方 Fragaria属には倍数性の異なる多様な野生種が知られて おり，ヨーロッパを中心に古くから植物学的研究が行わ れてきたが,これまでに育種に利用された事例は少ない. 実用的な成果としてはF. virginianaに由来する四季成性 (中日性)が挙げられる程度であり (Bringhust and Voth 1978），多くの実用形質に幅広い変異がみられる二倍性 野生種 $(2 \mathrm{n}=14)$ は育種にほとんど利用されていない.

低次倍数性野生種からの栽培イチゴへのゲノム導入に ついては，いくつかの方法が試みられてきた. 種間雑種 の複倍数体化は, 両親由来の遺伝子をたどりやすい点で 優れていると考えられるが, 稔性の高い複倍数体の効率 的作出がポイントとなる。野菜・茶業試験場では，二倍 性のFragaria属野生種のもつ優れた香気特性の導入を目 的に，八倍性 $(2 n=56)$ の栽培イチゴとの間に作出した五 倍性種間雑種から, 試験管内染色体倍加法により多数の 複倍数性種間雑種を作出した(森下ら 1996, Noguchi et al. 1997). 本法では, 不稔性の 5 倍性種間雑種個体のラ ンナー先端から摘出した茥頂組織を, コルヒチン, BA, NAAを添加した培地に置床し, 多数の側芽発生を促す ことにより, 倍加された分化植物体を高い確率で得るこ とができる。

この方法によりこれまでに，F. nilgerrensis，F. vesca， $F$. iinumae 等との間に複倍数性種間雑種が作出されてい る.これらの系統は, 栽培種に近い果実形質と野生種型 の香気成分特性を有しており, 栽培イチゴへの戻し交雑 による果実特性の改良を進められているが，野生種型の 香気を保持しつつ食味面でかなり改良された系統が得ら れている。なお複倍数性系統は，五倍体種間雑種のゲノ

表4. 栽培イチゴと2 倍性野生種との複倍数性種間雑種の特性(野菜茶試久留米支場，1997）

\begin{tabular}{llclcll}
\hline 品種・系統 & \multicolumn{1}{c}{ 交雑由来 } & 果重 $(\mathrm{g})$ & 果形 & 糖度 $(\%)$ & 香気特性 & 肉質 \\
\hline 久留米 IH 1 号 & とよのか $\times$ F. nilgerrensis & 18.3 & 円錐 & 8.55 & F. nilgerrensis & 粉質 \\
久留米 $\mathrm{IH}$ 2号 & F. vesca×女峰 & 10.0 & 球形 & 9.50 & F. vesca & スポンジ \\
久留米 IH 3 号 & F. vesca×アイベリー & 13.0 & 長球形 & 8.30 & F. vesca & スポンジ \\
とよのか & (栽培イチゴ品種) & 18.6 & 円錐 & 8.70 & 栽培イチゴ & 粘質 \\
\hline
\end{tabular}

久留米 $\mathrm{IH} 1$ 号 3 号 : 複倍数性種間雑誌 
ムをそのまま倍加しているため, 遺伝的にホモ化されて いることが想定されるが，このことは自殖第 1 代におけ る諸形質の個体間変異の調査から裏付けられている(望 月ら 1994).

\section{4）バイオテクノロジー利用}

イチゴでは遺伝子組換え研究は遅れていたが，浅尾ら (1995)がイネ由来キチナーゼ遺伝子をうどんこ病にり病 性の“とよのか’に導入し, 様々なレベルの抵抗性を付与 した系統を作出した。本研究を契機に国内でも取り組む 研究機関が徐々に増えつつあり, 特に病害抵抗性分野で の成果が期待される. また最近，ディファレンシアルデ イスプレー法等により果実成熟過程に特異的に発現する 遺伝子の解析が行われており, 遺伝子の単離と機能解析 が進めば，果実品質，特に着色性，流通適性，食味等の 遺伝的改変に発展することが期待される.

一方，DNA マーカー利用は育種の効率化に役立つ技 術として期待されるが，イチゴにおいて明確な成果が得 られた事例は，これまでのところオランダで開発された 疫病抵抗性遺伝子連鎖マーカーのみであり (Haymes et al. 1997），本マーカーについては最近 SCR マーカー化も報 告されている (Haymes et al. 2000). 最近わが国において も，炭そ病・うどんこ病抵抗性，ビタミンC含量等に関 するDNA マーカー検索が試みられているが，これらは 量的形質であることから, 純系作出が困難なイチゴに適 用可能な QTL解析手法等の開発が望まれる。また遺伝 様式は比較的単純であっても, 選抜のために出蕾・開花 まで養成する必要のある形質では，簡易に利用できる DNA マーカーが開発されれば育種が効率化される。こ れまでにPotentilla palustris 由来の赤花性に連鎖す RAPD マーカーが見出されており（雷ら 2000）, 四季成り性や
果房型等に連鎖するDNA マーカーも検討されている。

\section{8. 遺伝資源}

\section{1）遺伝資源の収集・保存}

農林水産省ジーンバンク事業の一環として, 現在野 菜・茶業試験場では久留米支場において栽培品種約 350 点, 近縁野生種約 200 点が保存され, 逐次特性調査が進 められており，また栄養体で保存する必要がある栽培品 種等については，茥頂組織の低温培養による長期保存が 図られている.しかし, 数千品種が保存されているアメ リカ (USDA/ARS)やロシア (バビロフ研究所) 等と比較 して, 保存のための専門組織が整備されていないわが国 が保有する遺伝資源は極めて少ない.

栽培イチゴの親となった八倍性野生種 F. chiloensis や F. virginianaについては，アメリカが中心となり，原産 地であるチリで組織的な収集・検討が行われている (Cameron et al. 1992). わが国でも野菜・茶業試験場が チリ国立農業研究所と共同で，チリ国内において $F$. chiloensisの探索・収集を行い(Mochizuki et al. 1996), 収 集された系統は, 日本のみに分布する二倍性野生種 $F$. iinumae, F. nipponica (亜種とされるF. yezoensis, F. yakushimensisを含む)，あるいは中国から導入された二 倍性野生種 $(F$. nilgerrensis, F. gracilis, F. nubicola) 等と ともに, 特性調査が進められている。

\section{2）近縁野生種}

Fragaria 属には幅広い倍数性の野生種が記載されてい るが,種間の類縁関係は必ずしも明らかにされておらず, また中国等の東アジア地域には, いくつかの学名不詳二 倍性種が確認されている。二倍性種間の交雑を除き, こ

表 5.イチゴ属 (Fragaria)の主要野生種

\begin{tabular}{|c|c|c|c|}
\hline 種名 & 倍数性 & 分布地域 & 特徵 \\
\hline Fragaria vesca & $2 \times$ & 北半球温帯～亜寒帯地域 & 変異大, 芳香, 四季成性 \\
\hline Fragaria viridis & $2 x$ & ヨーロッパ〜中央アジア & 立性，小果，芳香性 \\
\hline Fragaria nilgerrensis & $2 \times$ & 東南アジア〜中国南西部 & 多毛, 白実, モモ様香気 \\
\hline Fragaria daltoniana & $2 x$ & シッキム (3000-4000 m) & 小葉，紡錘型果，無味 \\
\hline Fragaria nubicola & $2 \times$ & 中央アジア〜シッキム & F. vesca類似, 雌雄異株 \\
\hline Fragaria iinumae & $2 \times$ & 日本(中部山岳以北) & 照葉, 落葉性, 6-8花弁 \\
\hline Fragaria nipponica & $2 x$ & 日本(中部山岳以北) & 小型，休眠性深，小果 \\
\hline Fragaria mandschurica & $2 \times$ & 中国東北地方 & F. orientalis の祖先種? \\
\hline Fragaria gracilis & $2 \times$ & 中国西部〜中央アジア？ & 果梗長く立性，小果 \\
\hline Fragaria orientalis & $4 \times$ & 西シベリア〜韓国 & まれに二期咲き, 微芳香 \\
\hline Fragaria moupinensis & $4 \times$ & 中国南西部 & 橙赤果, F. nilgerennsis 類似 \\
\hline Fragaria moschata & $6 x$ & 中部ヨーロッパ〜シベリア & 暗赤色大果, ムスク臭 \\
\hline Fragaria chiloensis & $8 \times$ & アラスカ〜チリ & 変異大(果色, 果重等) \\
\hline Fragaria virginiana & $8 \times$ & 北米中部～東部 & 赤色小果，変異大 \\
\hline Fragaria iturpensis & $8 \times$ & エトロフ島 & F. iinumae 類似, 球形小果 \\
\hline Fragaria $\times$ ananassa & $8 \times$ & 〈栽培種イチゴ〉 & 大果, 高糖 \\
\hline
\end{tabular}




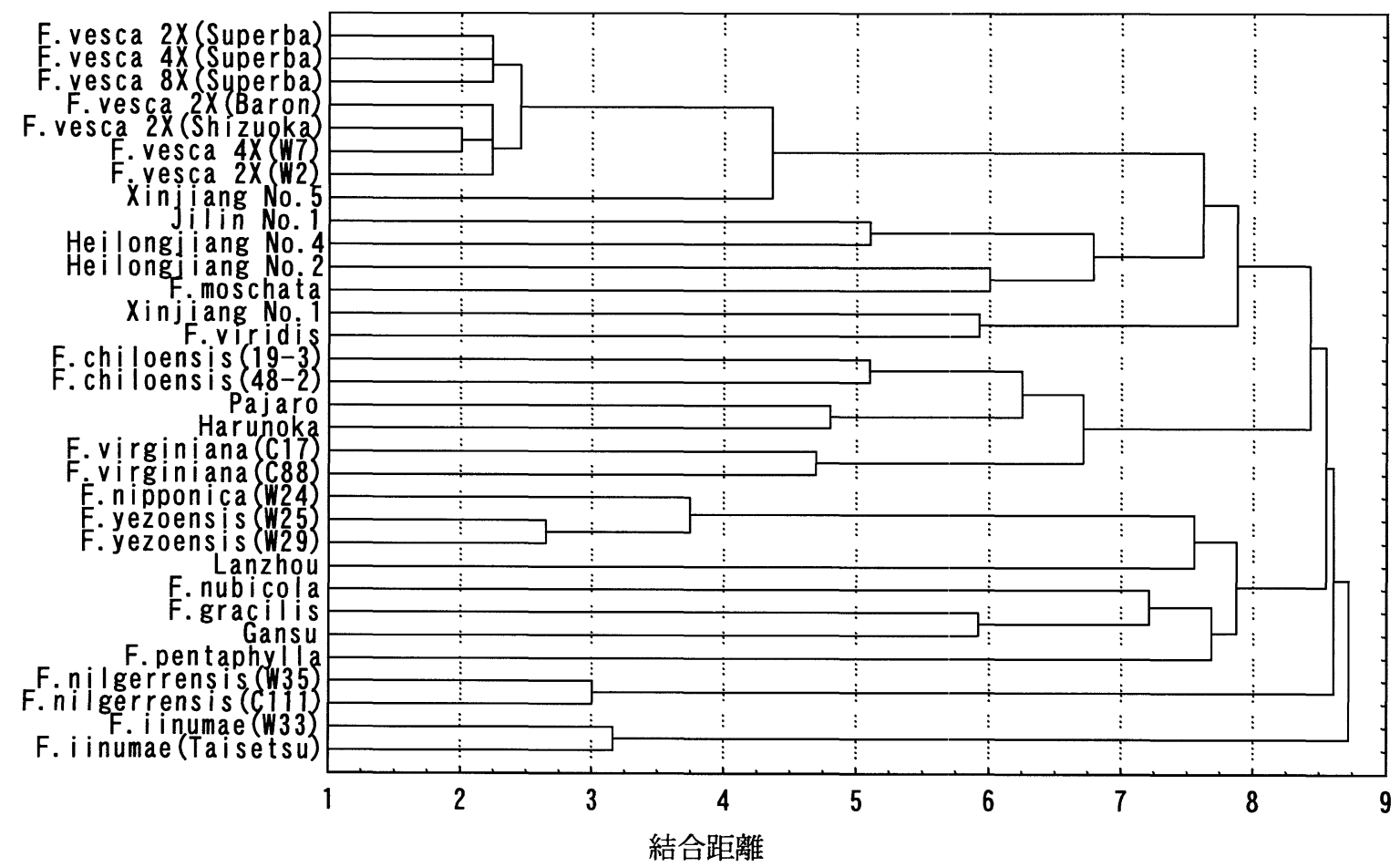

図 4.PCR-RAPD マーカーによる Fragaria 属野生種の類縁関係(雷ら 1999)

れらの種は互いにある程度交雑可能であり，またカリフ オルニアや中国東北地方では倍数性の異なる種からの浸 透交雑の結果と考えられる自生五倍体, 六倍体, 九倍体, 十倍体も見出されていることから, 高次倍数性種は二倍 性種を基本ゲノムとする自然複倍数体であるとも推定さ れるが，核型解析が困難なこともあり，高次倍数性種の ゲノム構成にまだ決定的な結論は得られていない.

野菜・茶業試験場と瀋陽農業大学は, 東アジア自生野 生種を含む幅広いFragaria属近縁野生種について，種間 交雑和合性とDNA マーカーを利用した系統分類の検討 に取り組み，東アジア，ヨーロッパ，アメリカ大陸等に 分布する Fragaria属植物について類縁関係を明らかにし つつある(李ら 1996, 雷ら 1999).

\section{9. おわりに}

現在のイチゴの育種目標は複雑かつ高度化しており, 小規模な試行錯誤的な育種，あるいは既存品種を直接交 配親に用いた育種のみでは十分な成果が期待できない. 近縁野生種を含む広範な遺伝資源の収集・評価，あるい は近年進歩の著しいゲノム解析技術等を利用した重要形 質に関する遺伝解析や選抜・評価法の開発等, 基礎的 · 基盤的研究の充実が必要である。

\section{引用文献}

浅尾浩史 - 荒井 滋 - 西澤洋子 - 佐藤隆徳 - 平井正志 - 日比忠 明 (1995) 育雑 45 (別 1): 141.

Bentvelsen, G. C. M. and E. Bouw (2000) 日本イチゴセミナー紀要
9: 62-67.

Bringhust, R. S. and V. Voth (1987) Genetics 98: 510.

Cameron, J. S., T. M. Sjulin, J. R. Ballington, C. H. Shanks, C. E. Munos and A. Lavin (1993) Acta Horticulturae 348: 65-74.

茶珍和雄・後藤隆子 (1992) 日本イチゴセミナー紀要 2: 93-98.

萩原章弘(1995) 日本イチゴセミナー紀要 4: 50-52.

Haymes, K. M., B. Henken, T. M. Davis and W. E. van de Weg (1997) TAG 94: 1097-1101.

Haymes, K. M., W. E. van de Weg, P. Arens, J. L. Maas, B. Vosman and A. P. M. Den Nijs (2000) J. Amer. Soc. Hort. Sci. 125: 330-339.

本多藤雄 (1983) 育種学最近の進歩 24: 45-52.

石原良行 - 高野邦治 - 植木正明 - 栃木博美(1996) 栃木農試研報 44: 109-123.

枳穀 豊 · 福原公昭 · 斉藤 喠 - 大田英明 (1995) 日食工誌 42: 118-123.

雷 家軍 · 望月龍也 - 野口裕司 - 曾根一純 (1999) 園学雑 68 (別 2): 133 .

雷 家軍 ·曽根一純 · 野口裕司 · 望月龍也 (2000) 園学雑 69(別 1): 244 .

李 玉花 · 望月龍也 ·野口裕司 - 曽根一純ら (1996) 園学雑 65 (別2): 306-307.

李 玉花·望月龍也・野口裕司 - 曽根一純 (1997) 園学雑 66 (別 1) : 268-269.

Meulenbroek, E. J., E. A. J. Hessel and C. P. van de Lindeloof (1996) Acta Horticulturae 439: 107-113.

望月龍也·森下昌三・野口裕司 - 曽根一純(1994) 育雑 44(別 2): 294.

望月龍也 · 野口裕司 - 曽根一純 · 三上哲一 ·若狭善彦 (1995) 園 学雑 64(別 1): 360-361.

望月龍也・野口裕司・曽根一純 (1996) 野菜茶試久留米支場研究 年報 8: 96-97. 
Mochizuki, T., A. Cubillos, A. Lavin, I. Matus, A. Torres, P. Leon, S. Suzuki and Y. Okawara (1996) Bull. Natl. Res. Inst. Veg., Ornam. Plants \& Tea Ser. A. 11: 119-130.

望月龍也 (1997) “昭和農業技術発達史”，農文協，5: 588-597.

Mochizuki, T., Y. Noguchi, K. Sone and M. Morishita (1997) Acta Horticulturae. 43: 75-80.

望月龍也・兽根一純 - 沖村 誠 (2000) 野菜茶試久留米支場研究 年報 13: 93-96.

門馬信二・上村昭二(1978) 野菜試報 B2: 1-11.

門馬信二・上村昭二(1985) 野菜試報 B5: 49-57.

森 利樹 (1998) 園学雑 67: 934-938.

森 利樹 (2000a) 園学雑 69(別 1): 99

森 利樹 (2000b) 園学雑 69: 90-96.

森下昌三 · 望月龍也 - 野口裕司 - 曽根一純 - 山川 理 (1997)野 菜茶試研報 12: 91-115.

森下昌三・山川 理 - 望月龍也 (1996) 野菜茶試研報 A.11: 69-95.

成川 昇. 石橋光治 - 荻原佐太郎 - 土岐知久 (1981) 千葉農試研 報 22: 45-55.

成川 昇·石川正美 (1997) 園学雑 66(別 2): 464-465.

Noguchi, Y., T. Mochizuki and O. Yamakawa (1994) Bull. Natl. Res. Inst. Veg., Ornam. Plants \& Tea Ser. A. 9: 13-26.

野口裕司 - 望月龍也 - 曽根一純 (1995) 園学雑 64 (別 1 ): 342-343.

Noguchi, Y., T. Mochizuki and K. Sone (1997) Abs. 94th ASHS
Annual International Conference. 91-115.

Noguchi, Y., T. Mochizuki and K. Sone (1998) Proc. XV EUCARPIA congress, 20.

荻原 勲 - 宮本 亮 · 羽布津真典 - 鈴木雅人 - 箱田直紀 · 志村 勲 (1998) 園学雑 67: 400-405.

沖村 誠·五十嵐勇 (1997) 野菜茶試報 12: 153-168.

沖村 誠(2000) 日本イチゴセミナー紀要 9: 15-23.

斉藤弥生子. 後藤昌人 (1997) 園学雑 66(別 2): 462-463.

斉藤弥生子. 番 喜宏. 菅原真治 (1998) 園学雑 67 (別 2): 327.

Simpson, D. W. (2000) 日本イチゴセミナー紀要 9: 24-34.

曽根一純 - 望月龍也 - 野口裕司 (1997) 園学雑 66(別 1): 284-285.

曽根一純 · 望月龍也 ·野口裕司 (1998) 園学雑 67 (別 2) : 320 .

兽根一純・望月龍也・野口裕司 (1999) 園学䧱 68: 1007-1014.

曽根一純 · 望月龍也・野口裕司 (2000) 園学雑 69(別 1) : 243.

竹内 隆 (1993) 静岡農試研報 37: 41-52.

Tamura, H., M. Takada and Y. Toshida (1995) Biosci. Biotech. Biochem. 59: 1157-1158.

田中和夫 (1998) “イチゴ品種と新技術”, 誠文堂新光社, 166-174.

内田景子 · 井上治郎 (1998) 植物防疫 52: 224-227.

山口雅篤 · 松添直隆 · 川信修二 ・曽根一純 - 望月龍也 (1999) 園 学雑 68 (別 2): 134

柳 智博 (1992) 大阪府大紀要 (農学 ·生物学) 43: 115-144.

柳 智博 (2000) 日本イチゴセミナー紀要 9: 102-108. 